\title{
Influence of Species, Clone, Propagation Method, and Animal Waste Application during Establishment on Growth and Productivity of 21-Year-Old Paulownia Trees
}

\author{
Ben A. Bergmann ${ }^{1, *}$, Solomon B. Ghezehei ${ }^{2}$ \\ ${ }^{1}$ Department of Horticultural Science, North Carolina State University, United States \\ ${ }^{2}$ Department of Forestry and Environmental Resources, North Carolina State University, United States
}

Copyright $\bigcirc 2019$ by authors, all rights reserved. Authors agree that this article remains permanently open access under the terms of the Creative Commons Attribution License 4.0 International License

\begin{abstract}
Paulownia elongata, Paulownia fortunei, and Paulownia $\times$ 'Henan 1' were grown for 21 years to determine growth and productivity potential of Paulownia in North Carolina, USA. One site included P. elongata only and was designed to test variability among clones within the species and the influence of application of dairy cow or poultry litter during the first six years. A second site was used to examine influence of species, clone, and propagation method. Species and clone within species frequently influenced tree performance, indicating that the planting of select clones could increase yields. By using the best approximately one-third of clones rather than all clones, tree survival could increase from $74 \%$ to $98 \%$, and individual tree productivity as estimated by stem dry mass could increase by $21 \%$. Trees of all three species grown from seed had lower survival, and seed-propagated trees that survived had inferior growth compared to trees of the same species grown from rooted shoot cuttings or microshoots from tissue culture. Application of dairy cow waste or poultry litter during the first six years did not influence tree survival or height to live crown, but early application of either animal waste resulted in taller trees compared to the control trees. Trees established with poultry litter applications had greater stump diameter, diameter breast height, stem volume, and stem dry mass than trees in the dairy cow waste or water-only control treatments.
\end{abstract}

Keywords Animal Waste, Clones, Fast-growing Trees, Princess Tree, Propagation, Stem Biomass, Tree Volume

\section{Introduction}

Though its native range is almost entirely within southeastern China, Paulownia is often considered for planting in many areas of the world because some of the nine species within the genus are known to be valuable for many reasons. Examples include afforestation [1], agroforestry systems [2], honey production and medicinal uses [3], biomass production [4, 5], heavy metal bioremediation [6], intercropping systems [7, 8], livestock fodder production [9, 10], livestock waste remediation [11], mine site reclamation [12], and wood production and solid wood products $[1,13]$. Royal paulownia $[P$. tomentosa (Thunb.) Steud.] has received the most attention in the United States $[14,15]$ because it has been naturalized in the southeastern part of the country for over 150 years [16]. Our focus turned to $P$. elongata S.Y. Hu, $P$. fortunei (Seem.) Hemsley, and a cross between the two species called $P$. $\times$ 'Henan 1', named for the province in China in which it was selected, because early trials indicated that they can out yield $P$. tomentosa in managed small woodlots in North Carolina (Bergmann, unpublished).

This research was conducted to determine the survival and growth potential for $P$. elongata, $P$. fortunei, and $P$. $\times$ 'Henan 1' in the piedmont of North Carolina, USA. Additional insights were sought regarding influences of clone within species, propagation method, and animal waste applications during tree establishment. This paper includes findings from 21-year-old trees at two sites for which 5-year results have been reported as part of a larger project [17]. 


\section{Materials and Methods}

Long-term Paulownia field trials were established at two sites in North Carolina in 1996: Site 1 in the central piedmont and Site 2 in the upper piedmont of the state. Each site had study aims and maintenance practices tailored to it.

\subsection{Plant Material}

Paulownia elongata, P. fortunei, and P. × 'Henan 1' plants were produced in three ways from bulk seed as described earlier [18, 19]. Plants were: a) grown directly from seed, b) propagated by rooting stem cuttings from greenhouse stock plants, or c) propagated by rooting microshoots from tissue culture. Vegetatively propagated plants were produced from seedlings grown from the same seedlots used to grow plants from seed. Plants produced by all propagation methods were grown to approximately 10 $\mathrm{cm}$ in the greenhouse before placing them outdoors for two to four weeks to acclimatize prior to field planting.

\subsection{Field Establishment}

Plants between 15 and $30 \mathrm{~cm}$ were planted in the field at a spacing of $4.3 \mathrm{~m} \times 4.3 \mathrm{~m}$ after ripping the soil to a depth of $30 \mathrm{~cm}$ down the middle of rows from which vegetation was killed two weeks earlier by glyphosate application along 1-m wide strips. Trees of a random mix of the genotypes used in the experiment were planted at the same spacing to serve as border trees on all sides of each planting and between treatments within a site. Each tree received approximately $8 \mathrm{~L}$ water at planting and each week for four weeks thereafter if the site did not receive at least $2.5 \mathrm{~cm}$ rainfall that week.

\subsection{Field Maintenance}

During the first growing season (1996), a 1-m diameter area around each tree was kept weed free, the rest of the area was mowed to reduce weed competition, and trees were maintained as single stems but allowed to branch. Trees were cut to the ground during the winter following the first growing season (early 1997). As multiple stump sprouts emerged early in the second growing season, all were removed except one stem that was healthy, vigorous, and firmly attached to the stump. Maintenance the second year included removing weeds from a 1-m diameter area around each tree, keeping the rest of the area mowed, and periodically removing axillary breaks to retain a single, non-branched trunk. Starting in the third year, branch-free trunks were maintained by removing any shoots that emerged on trunks up to $5 \mathrm{~m}$, and the area under the trees was mowed periodically. Tree trunks broken in high winds or snow/ice storms were pruned to encourage a new leader if the break was above $2 \mathrm{~m}$ or cut to the ground to start a new straight trunk if the break was below $2 \mathrm{~m}$.

Trees were harvested near the end of the 2016 growing season. Thus, we report results from 21-year-old trees including the first year before trees were coppiced.

\subsection{Methods Specific to Site 1}

The trial was planted in mid-June 1996 at the NCSU Piedmont Research Station (36 ${ }^{\circ} 22^{\prime} 46.488^{\prime \prime} \mathrm{N}, 79^{\circ} 41^{\prime}$ 40.3476" W) and included P. elongata clones and animal waste applications during establishment as treatments. Twelve clones propagated through tissue culture were used, and animal waste applications were dairy cow waste, poultry litter, or nothing as a control. Animal waste was applied only once the first year to allow sufficient tree establishment time. The single application was equivalent to 21 and $48 \mathrm{~kg} /$ ha plant available nitrogen (PAN) from the dairy cow and poultry sources, respectively. During the next five years, animal waste was applied as a row side-dressing to achieve a PAN rate of approximately 200 $\mathrm{kg} / \mathrm{ha} / \mathrm{yr}$. This was accomplished with a single application of poultry litter in May or June or applications of cow waste once per month in May, June, and August. Plots of 12 trees, one from each $P$. elongata clone positioned at random, were assigned to animal waste treatments at random. Blocks contained three plots, one for each animal waste treatment. The trial included 144 treatment trees: one 12-tree plot for each of three animal waste treatments in each of two blocks within each of two replicates. Replication sites were $600 \mathrm{~m}$ apart.

\subsection{Methods Specific to Site 2}

The trial was planted in early May 1996 at the NCSU Upper Piedmont Research Station (35² 41' 48.0012" N, 80 37' 21.63" W) and included propagation method, species, and clone within species as treatments. Propagation methods were seed, rooted stem cuttings, and rooted microshoots produced through tissue culture. Species were $P$. elongata, $P$. fortunei, and $P$. × 'Henan 1 ', the last of these being a hybrid between the first two species and treated as a species in this work. Trees for the clone treatment were produced through tissue culture: seven clones for $P$. elongata, three clones for $P$. fortunei, and four clones for $P$. × 'Henan 1'. Trees were fertilized with $75 \mathrm{~kg}$ $\mathrm{N} / \mathrm{ha} / \mathrm{yr}$ in mid-July for the first six years. Occasional mowing was used to control understory vegetation for the first five years, and thereafter cattle were periodically allowed to graze the site to achieve the same goal. Blocks consisted of 20 trees, one tree from each species propagated by seed or stem cuttings and one from each of the 14 clones propagated by tissue culture. The trial included 240 treatment trees: six 20-tree blocks within each of two replicates. Replication sites were immediately adjacent to one another.

\subsection{Data Collection and Statistical Analysis}

Recorded data prior to harvest included diameter breast height (DBH, $1.4 \mathrm{~m}$ from soil), height to live crown, and 
total tree height. Stump diameter (30 cm from soil) was recorded following harvest by measuring the widest and narrowest lengths across the center and averaging the two values because of the pronounced lower trunk asymmetry in some trees. Individual tree volume was calculated by dividing the stem into three parts: a base part with a truncated-cone form, a cylindrical section of the stem (from breast height to live-crown height) and a conical top part of the stem (from crown base to tree top). Stem biomass was calculated by multiplying tree volume by species wood density obtained from the wood density database of the world agroforestry center [20].

Statistical analyses were conducted in JMP 13.2 (SAS Institute, Cary, NC, USA). The general linear model procedure was used for analyses of variance because it was common for data to be unbalanced, either intentionally (e.g. different number of clones per species) or through missing observations (e.g. tree mortality, storm damaged trees). Replicate and block within replicate were included as random effects in the analyses. The imposed treatments of propagation method, species, clone within species, and animal waste application were considered fixed effects. Differences between pairs of treatments were identified using Student's t test for pairwise comparisons of means.

\section{Results}

\subsection{Results Specific to Site 1}

Paulownia elongata tree survival across animal waste treatments and clones was 74\%. Survival did not differ among dairy cow waste, poultry litter, and no-waste control treatments, but survival of clones differed significantly $(P<0.0001)$ and ranged from 33 to $100 \%$ (Table 1). Stump diameter and DBH were influenced by animal waste treatment $(P<0.0001$ for both) and clone $(P=0.0004$ and $P<0.0001$, respectively), with both being greater for trees established with poultry litter applications as compared to dairy cow waste treated and control trees which did not differ from each other (Table 1). Height to live crown was uniform among animal waste treatments and clones, but total height was less for control trees than for trees in the two animal waste treatments $(P=0.0092)$ which did not differ from each other (Table 1 ). Clones differed greatly in total tree height $(P=0.0009)$, ranging from $14.5 \mathrm{~m}$ to $23.5 \mathrm{~m}$. Interaction between animal waste treatment and clone was never significant for any dependent variable.

Replicates differed in DBH $(P=0.0002)$ and height to live crown $(P=0.0008)$ as did blocks within replicate ( $P=0.0092$ and $P=0.0478$, respectively), but neither of these random effects interacted significantly with the effect of animal waste treatment or clone. It is likely that greater wind damage in one of the replicates and in one of the blocks within that replicate due to different environmental exposure accounts for the differences.

The calculated variables stem volume and stem dry mass were significantly influenced by animal waste but not clone treatments (Table 1). The differences among animal waste treatments for stem volume and stem dry mass followed the stump diameter and DBH trends more than the height to live crown and total height trends (Table 1).

Table 1. Influence of animal waste application during the first six year and clone on growth characteristics of 21-year-old Paulownia elongate trees (values within a trait and treatment group followed by the same letter not different at the $P=0.05$ level)

\begin{tabular}{|c|c|c|c|c|c|c|c|c|c|}
\hline \multirow[b]{2}{*}{ Treatment } & \multirow[b]{2}{*}{$\begin{array}{c}\text { Survival } \\
(\%)\end{array}$} & \multirow{2}{*}{$\begin{array}{c}\text { Stump } \\
\text { Diameter } \\
(\mathrm{cm})\end{array}$} & \multirow[b]{2}{*}{$\begin{array}{c}\text { DBH } \\
(\mathbf{c m})\end{array}$} & \multicolumn{2}{|c|}{ Height (m) } & \multicolumn{2}{|c|}{ Stem volume $\left(\mathbf{m}^{3}\right)$} & \multicolumn{2}{|c|}{ Stem mass (kg) } \\
\hline & & & & $\begin{array}{l}\text { To live } \\
\text { crown }\end{array}$ & Total & $\begin{array}{l}\text { To live } \\
\text { crown }\end{array}$ & Total & $\begin{array}{l}\text { To live } \\
\text { crown }\end{array}$ & Total \\
\hline \multicolumn{10}{|l|}{ Animal waste: } \\
\hline Dairy cow & $83 \mathrm{a}$ & $59 \mathrm{~b}$ & $47 \mathrm{~b}$ & $12.5 \mathrm{a}$ & $21.9 \mathrm{a}$ & $2.2 \mathrm{~b}$ & $2.8 \mathrm{~b}$ & $508 \mathrm{~b}$ & $650 \mathrm{~b}$ \\
\hline Poultry litter & $71 \mathrm{a}$ & $72 \mathrm{a}$ & $57 \mathrm{a}$ & $12.7 \mathrm{a}$ & $22.3 \mathrm{a}$ & $3.1 \mathrm{a}$ & $3.9 \mathrm{a}$ & $706 \mathrm{a}$ & $905 \mathrm{a}$ \\
\hline None & $67 \mathrm{a}$ & $55 \mathrm{~b}$ & $42 \mathrm{~b}$ & $12.9 \mathrm{a}$ & $19.8 \mathrm{~b}$ & $2.1 \mathrm{~b}$ & $2.5 \mathrm{~b}$ & $477 \mathrm{~b}$ & $567 \mathrm{~b}$ \\
\hline \multicolumn{10}{|l|}{ Clone: } \\
\hline 1 & $50 \mathrm{de}$ & $46 \mathrm{~d}$ & $36 \mathrm{~d}$ & $10.8 \mathrm{a}$ & $16.7 \mathrm{bc}$ & $1.4 \mathrm{a}$ & $1.6 \mathrm{a}$ & $325 \mathrm{a}$ & $367 \mathrm{a}$ \\
\hline 2 & 67 bcd & $61 \mathrm{abc}$ & $48 \mathrm{abc}$ & $13.9 \mathrm{a}$ & $22.9 \mathrm{a}$ & $2.5 \mathrm{a}$ & $3.2 \mathrm{a}$ & $570 \mathrm{a}$ & $726 \mathrm{a}$ \\
\hline 4 & $33 \mathrm{e}$ & $49 \mathrm{~cd}$ & $38 \mathrm{~cd}$ & $14.9 \mathrm{a}$ & $23.5 \mathrm{a}$ & $1.6 \mathrm{a}$ & $2.1 \mathrm{a}$ & $374 \mathrm{a}$ & $477 \mathrm{a}$ \\
\hline 6 & $92 \mathrm{ab}$ & $68 \mathrm{a}$ & $52 \mathrm{a}$ & $11.2 \mathrm{a}$ & $21 \mathrm{ab}$ & $2.7 \mathrm{a}$ & $3.3 \mathrm{a}$ & $618 \mathrm{a}$ & $768 \mathrm{a}$ \\
\hline 8 & $100 \mathrm{a}$ & $68 \mathrm{a}$ & $54 \mathrm{a}$ & $12.9 \mathrm{a}$ & $23.2 \mathrm{a}$ & $2.6 \mathrm{a}$ & $3.5 \mathrm{a}$ & $598 \mathrm{a}$ & 801 a \\
\hline 9 & $100 \mathrm{a}$ & $64 \mathrm{ab}$ & $52 \mathrm{a}$ & $12.5 \mathrm{a}$ & $22.8 \mathrm{a}$ & $2.6 \mathrm{a}$ & $3.4 \mathrm{a}$ & $596 \mathrm{a}$ & $776 \mathrm{a}$ \\
\hline 10 & $100 \mathrm{a}$ & $64 \mathrm{abc}$ & $53 \mathrm{a}$ & $13.4 \mathrm{a}$ & $23.1 \mathrm{a}$ & $2.6 \mathrm{a}$ & $3.4 \mathrm{a}$ & $590 \mathrm{a}$ & $782 \mathrm{a}$ \\
\hline 11 & $92 \mathrm{ab}$ & $62 \mathrm{abc}$ & $52 \mathrm{ab}$ & $13.1 \mathrm{a}$ & $22.5 \mathrm{a}$ & $2.9 \mathrm{a}$ & $3.5 \mathrm{a}$ & $658 \mathrm{a}$ & $816 \mathrm{a}$ \\
\hline 12 & $83 \mathrm{abc}$ & $64 \mathrm{ab}$ & $51 \mathrm{ab}$ & $12.6 \mathrm{a}$ & $20.4 \mathrm{ab}$ & $2.9 \mathrm{a}$ & $3.4 \mathrm{a}$ & $660 \mathrm{a}$ & $770 \mathrm{a}$ \\
\hline 17 & $42 \mathrm{de}$ & 56 abcd & $40 \mathrm{bcd}$ & $9.3 \mathrm{a}$ & $14.5 \mathrm{c}$ & $1.8 \mathrm{a}$ & $1.9 \mathrm{a}$ & $406 \mathrm{a}$ & $433 \mathrm{a}$ \\
\hline 39 & $67 \mathrm{bcd}$ & $63 \mathrm{abc}$ & 48 abcd & $13.4 \mathrm{a}$ & $20.8 \mathrm{ab}$ & $2.4 \mathrm{a}$ & $3.1 \mathrm{a}$ & $562 \mathrm{a}$ & $705 \mathrm{a}$ \\
\hline 64 & $58 \mathrm{cde}$ & $53 \mathrm{bcd}$ & $40 \mathrm{~cd}$ & $13.5 \mathrm{a}$ & $19.3 \mathrm{abc}$ & $1.5 \mathrm{a}$ & $1.9 \mathrm{a}$ & $352 \mathrm{a}$ & $433 \mathrm{a}$ \\
\hline All clones & 74 & 60 & 48 & 12.6 & 20.9 & 2.3 & 2.9 & 526 & 655 \\
\hline
\end{tabular}




\subsection{Results Specific to Site 2}

Tree survival across propagation methods, Paulownia species, and clones within species was $77 \%$. Propagation method influenced survival $(P=0.0126)$ with trees grown from rooted stem cuttings or microshoots surviving equally and at a much higher frequency than trees grown from seed (Table 2). Species did not influence survival, but clone did with survival frequencies ranging from 67 to $100 \%$ (Table 2). Stump diameter and DBH were influenced by propagation method $(P<0.0001$ for both $)$, species ( $P=0.0062$ and $P<0.0001$, respectively), and clone within species $(P<0.0001$ for both). Both diameters were greater for trees grown from rooted stem cuttings or microshoots than for trees grown from seed, and the two vegetative propagation methods did not differ from each other (Table 2). The hybrid $P . \times$ 'Henan 1' had smaller DBH than did the species $P$. elongata and $P$. fortunei, which did not differ from each other (Table 2). Stump diameter among clones ranged from $52 \mathrm{~cm}$ to $69 \mathrm{~cm}$, and DBH ranged from $38 \mathrm{~cm}$ to $51 \mathrm{~cm}$ (Table 2). Height to live crown and total tree height were influenced by propagation method $(P<0.0001$ for both), species ( $P=0.0414$ and $P=0.0069$, respectively), and clone within species ( $P<0.0001$ for both). Both heights were greater for trees grown from rooted stem cuttings or microshoots than for trees grown from seed (Table 2). Height to live crown did not differ between the two vegetative propagation methods, but microshoot-produced trees were taller than trees grown from rooted cuttings (Table 2). Paulownia elongata had greater height to live crown and total height than did $P$. fortunei and $P . \times$ 'Henan
1 ' which did not differ from each other (Table 2). Height to live crown among clones ranged from $15.3 \mathrm{~m}$ to $19.3 \mathrm{~m}$, and total tree height ranged from $23.2 \mathrm{~m}$ to $29.7 \mathrm{~m}$ (Table 2).

In no case did replicate or block within replicate significantly influence a dependent variable, and neither of these random effects interacted significantly with the effect of propagation method, Paulownia species, or clone within species. The only cases of significant interactions between treatments were between propagation method and species for height to live crown $(P=0.0002)$ and total tree height $(P<0.0001)$. These interactions reflect a different influence of propagation method on the species for these two traits. Paulownia fortunei and $P . \times$ 'Henan 1' trees grown from seed had a much shorter height to live crown compared to trees grown from stem cuttings or microshoots, whereas this difference was less pronounced for $P$. elongata (Fig. 1). Paulownia elongata and $P$. fortunei trees grown from microshoots had greater total tree height than those grown from stem cuttings or seed, but for $P . \times$ 'Henan 1 ' trees grown from stem cuttings were as tall as those grown from microshoots (Fig. 1).

The calculated variables stem volume and stem dry mass were significantly influenced by propagation method, species, and clone treatments (Table 2). This included significant differences among the seven $P$. elongata clones and among the four $P$. × 'Henan 1' clones but not among the three $P$. fortunei clones (Table 2). The trend in values for stem volume and stem dry mass among propagation methods, species, and clones were most similar to those for DBH (Table 2).

Table 2. Influence of propagation method, species, and clone within species on growth characteristics of 21-year-old paulownia trees (values within a trait and treatment group followed by the same letter not different at the $P=0.05$ level)

\begin{tabular}{|c|c|c|c|c|c|c|c|c|c|}
\hline \multirow[b]{2}{*}{ Treatment } & \multirow[b]{2}{*}{$\begin{array}{c}\text { Survival } \\
(\%)\end{array}$} & \multirow{2}{*}{$\begin{array}{c}\text { Stump } \\
\text { Diameter } \\
\text { (cm) }\end{array}$} & \multirow[b]{2}{*}{$\begin{array}{c}\text { DBH } \\
(\mathrm{cm})\end{array}$} & \multicolumn{2}{|c|}{ Height (m) } & \multicolumn{2}{|c|}{ Stem volume $\left(\mathrm{m}^{3}\right)$} & \multicolumn{2}{|c|}{ Stem mass (kg) } \\
\hline & & & & $\begin{array}{l}\text { To live } \\
\text { crown }\end{array}$ & Total & $\begin{array}{l}\text { To live } \\
\text { crown }\end{array}$ & Total & $\begin{array}{l}\text { To live } \\
\text { crown }\end{array}$ & Total \\
\hline \multicolumn{10}{|l|}{ Propagation method: } \\
\hline Seed & $56 \mathrm{~b}$ & $38 \mathrm{~b}$ & $28 \mathrm{~b}$ & $12.1 \mathrm{~b}$ & $23.5 \mathrm{~b}$ & $0.8 \mathrm{~b}$ & $0.9 \mathrm{~b}$ & $185 \mathrm{~b}$ & $214 b$ \\
\hline Stem cuttings & $81 \mathrm{a}$ & $59 \mathrm{a}$ & $43 \mathrm{a}$ & $15.9 \mathrm{a}$ & $25.4 \mathrm{a}$ & $2.4 \mathrm{a}$ & $2.8 \mathrm{a}$ & $588 \mathrm{a}$ & $684 \mathrm{a}$ \\
\hline Microshoots & $80 \mathrm{a}$ & $57 \mathrm{a}$ & $46 \mathrm{a}$ & $16.6 \mathrm{a}$ & $18.1 \mathrm{c}$ & $2.7 \mathrm{a}$ & $3.1 \mathrm{a}$ & $636 \mathrm{a}$ & $744 \mathrm{a}$ \\
\hline \multicolumn{10}{|l|}{ Species: } \\
\hline P. elongata & $78 \mathrm{a}$ & $58 \mathrm{a}$ & $43 \mathrm{a}$ & $16.7 \mathrm{a}$ & $25.3 \mathrm{a}$ & $2.8 \mathrm{a}$ & $3.0 \mathrm{a}$ & $593 \mathrm{ab}$ & $693 \mathrm{ab}$ \\
\hline P. fortunei & $72 \mathrm{a}$ & $53 \mathrm{~b}$ & $44 \mathrm{a}$ & $15.3 \mathrm{~b}$ & $23.1 \mathrm{~b}$ & $2.5 \mathrm{a}$ & $2.9 \mathrm{a}$ & $636 \mathrm{a}$ & $743 \mathrm{a}$ \\
\hline P. $\times$ 'Henan 1' & $79 \mathrm{a}$ & $56 \mathrm{ab}$ & $38 \mathrm{~b}$ & $15.6 \mathrm{~b}$ & $23.7 \mathrm{~b}$ & $2.1 \mathrm{~b}$ & $2.5 \mathrm{~b}$ & $517 \mathrm{~b}$ & $603 \mathrm{~b}$ \\
\hline \multicolumn{10}{|l|}{ Clone: } \\
\hline P. elongata 1 & $83 \mathrm{ab}$ & $56 \mathrm{~cd}$ & $43 \mathrm{~d}$ & $16.2 \mathrm{~cd}$ & $24.6 \mathrm{~cd}$ & $2.3 \mathrm{def}$ & $2.7 \mathrm{def}$ & $524 \mathrm{de}$ & $611 \mathrm{de}$ \\
\hline P. elongata 2 & $83 \mathrm{ab}$ & $57 \mathrm{~cd}$ & $42 \mathrm{de}$ & $16.3 \mathrm{~cd}$ & $24.6 \mathrm{~cd}$ & 2.4 cdef & $2.8 \mathrm{cdef}$ & $560 \mathrm{cde}$ & $651 \mathrm{cde}$ \\
\hline P. elongata 3 & $75 \mathrm{ab}$ & $67 \mathrm{ab}$ & $50 \mathrm{ab}$ & $18.5 \mathrm{ab}$ & $28.6 \mathrm{ab}$ & $3.7 \mathrm{ab}$ & $4.3 \mathrm{ab}$ & $847 \mathrm{ab}$ & $998 \mathrm{ab}$ \\
\hline P. elongata 4 & $83 \mathrm{ab}$ & $56 \mathrm{~cd}$ & $41 \mathrm{de}$ & $15.9 \mathrm{~cd}$ & $23.9 \mathrm{~cd}$ & 2.2 def & $2.5 \mathrm{ef}$ & $497 \mathrm{de}$ & $577 \mathrm{de}$ \\
\hline P. elongata 7 & $100 \mathrm{a}$ & $69 \mathrm{a}$ & $51 \mathrm{ab}$ & $19.3 \mathrm{a}$ & $29.7 \mathrm{a}$ & $4.1 \mathrm{a}$ & $4.8 \mathrm{a}$ & $936 \mathrm{a}$ & $1,098 \mathrm{a}$ \\
\hline P. elongata 8 & $83 \mathrm{ab}$ & $57 \mathrm{~cd}$ & $41 \mathrm{de}$ & $15.9 \mathrm{~cd}$ & $24.3 \mathrm{~cd}$ & $2.2 \mathrm{def}$ & $2.6 \mathrm{def}$ & $507 \mathrm{de}$ & $593 \mathrm{de}$ \\
\hline P. elongata 9 & $67 \mathrm{~b}$ & $56 \mathrm{~cd}$ & $42 \mathrm{de}$ & $15.7 \mathrm{~cd}$ & $24.2 \mathrm{~cd}$ & $2.2 \mathrm{def}$ & $2.6 \mathrm{def}$ & $512 \mathrm{de}$ & $600 \mathrm{de}$ \\
\hline P. fortunei 4 & $75 \mathrm{ab}$ & $58 \mathrm{c}$ & $48 \mathrm{bc}$ & $16.6 \mathrm{c}$ & $25.3 \mathrm{c}$ & $2.7 \mathrm{cdef}$ & 3.2 cdef & 699 bcd & 815 bcd \\
\hline P. fortunei 24 & $67 \mathrm{~b}$ & $57 \mathrm{~cd}$ & $46 \mathrm{c}$ & $16 \mathrm{~cd}$ & $24.2 \mathrm{~cd}$ & 3.0 bcde & 3.5 bcde & $766 \mathrm{abc}$ & $900 \mathrm{abc}$ \\
\hline P. fortunei 36 & $75 \mathrm{ab}$ & $58 \mathrm{c}$ & $48 \mathrm{bc}$ & $16.5 \mathrm{~cd}$ & $25.4 \mathrm{c}$ & $3.0 \mathrm{bcd}$ & $3.6 \mathrm{bcd}$ & $782 \mathrm{ab}$ & $915 \mathrm{ab}$ \\
\hline P. $\times$ 'Henan 1' 4 & $83 \mathrm{ab}$ & $56 \mathrm{~cd}$ & 40 def & $16.3 \mathrm{~cd}$ & $24.5 \mathrm{~cd}$ & 2.1 ef & $2.4 \mathrm{f}$ & $514 \mathrm{de}$ & $597 \mathrm{de}$ \\
\hline P. $\times$ 'Henan 1' 6 & $100 \mathrm{a}$ & $65 \mathrm{~b}$ & $47 \mathrm{c}$ & $17.9 \mathrm{~b}$ & $27.5 \mathrm{~b}$ & $3.2 \mathrm{abc}$ & $3.6 \mathrm{abc}$ & $776 \mathrm{abc}$ & $909 \mathrm{ab}$ \\
\hline P. $\times$ 'Henan 1' 9 & $75 \mathrm{~b}$ & $52 \mathrm{~d}$ & 39 ef & $15.3 \mathrm{~d}$ & $23.4 \mathrm{~d}$ & $1.9 \mathrm{f}$ & $2.2 \mathrm{f}$ & $452 \mathrm{e}$ & $527 \mathrm{e}$ \\
\hline P. $\times$ 'Henan 1' 16 & $75 \mathrm{~b}$ & $54 \mathrm{~cd}$ & $38 \mathrm{f}$ & $15.5 \mathrm{~cd}$ & $23.2 \mathrm{~d}$ & $1.9 \mathrm{f}$ & $2.1 \mathrm{f}$ & $451 \mathrm{e}$ & $524 \mathrm{e}$ \\
\hline All clones & 77 & 58 & 44 & 16.6 & 25.2 & 2.6 & 3.1 & 630 & 737 \\
\hline
\end{tabular}




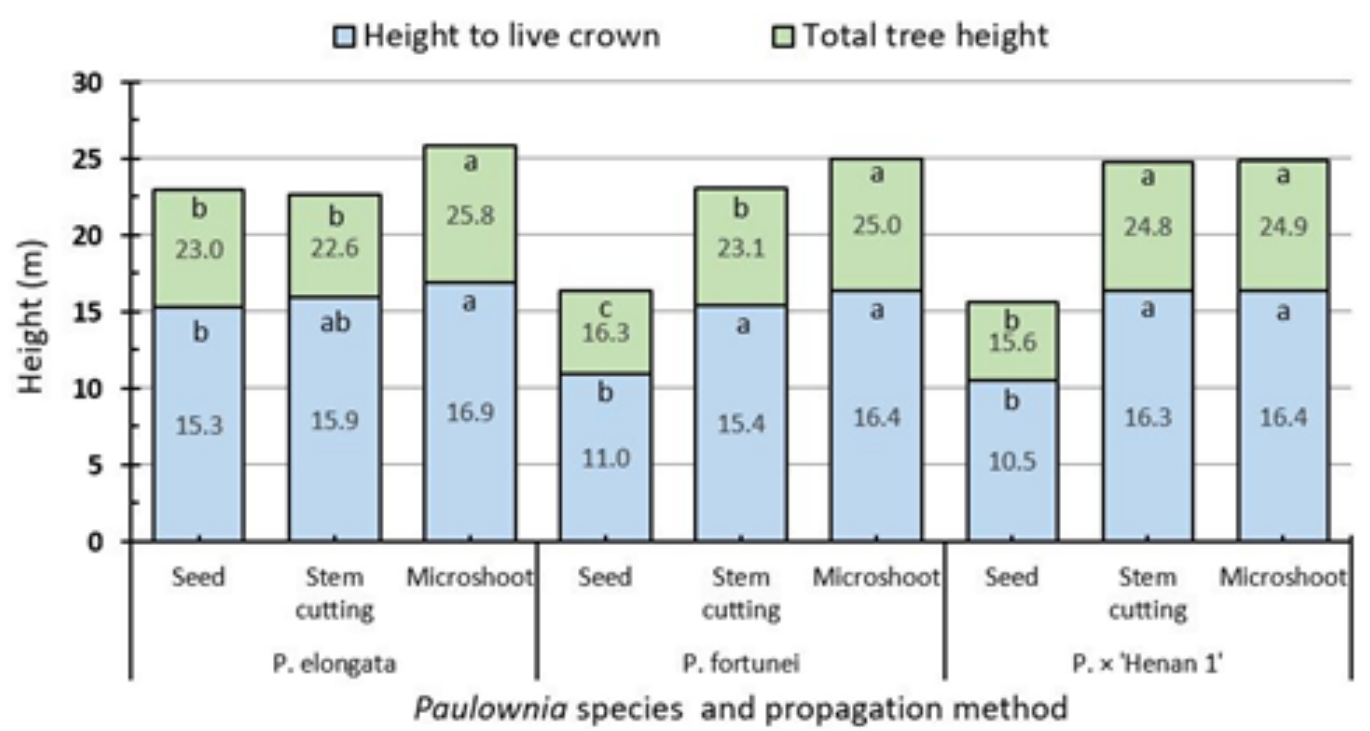

Figure 1. Influence of Paulownia species and propagation method after 21 years on trunk height to live crown and total tree height (means for propagation method within a species and trait topped by the same letter not different at the $P=0.05$ level)

\section{Discussion}

\subsection{Species and Clones}

As was found in assessments at five years of these same trees [17], selection of correct species and optimally performing clones can greatly increase Paulownia survival and productivity in the North Carolina piedmont. For example, using only the top four performing $P$. elongata clones at Site 1 (33\% of the clones in the trial) could have increased tree survival from $74 \%$ to $98 \%$ and productivity by $21 \%$ as estimated by stem dry mass. Paulownia elongata clones \#4 and \#17 were characterized as "of notably worse performance" at year five, but clones did not differ in stem biomass after 21 years, though they were among the four most lowly ranked clones: \#1 followed by $\# 17, \# 64$ and \#4. Avoiding the planting of these poorly performing clones could afford significant productivity improvements. Likewise, using the best two $P$. elongata clones, the best $P$. fortunei clone, and the best $P . \times$ 'Henan 1 ' clone at Site 2 (29\% of the clones in the trial) could have increased tree survival from $77 \%$ to $90 \%$ and productivity by $25 \%$ as estimated by stem dry mass. Likewise, not planting $P . \times$ 'Henan 1 ' and using $P$. elongata or $P$. fortunei only would greatly enhance productivity. Similarly, Dong and Van Buijtenen [21] previously showed the superior performance of $P$. fortunei compared to $P$. tomentosa in Texas, USA.

At Site 1, while there were significant clonal differences in stump diameter, $\mathrm{DBH}$, and total tree height, clones did not differ in stem volume or biomass on a per tree basis. However, if survival frequency were incorporated into a calculation of stem volume or biomass on a land area basis, clone differences would be amplified. This is seen in looking at the three clones with the lowest survival (averaging 42\%) which also had the lowest total stem mass (averaging $426 \mathrm{~kg}$ ) compared to the three clones with highest survival (100\% for all three) which had three of the four highest total stem mass values (averaging $786 \mathrm{~kg}$ ). It is interesting that $P$. elongata clones did not differ in stem volume or stem mass at Site 1 but did at Site 2, even though there were 12 clones at the former and seven at the later. This might be explained by the confounding effect of different treatments imposed at the two sites or the homogenizing effect of wind damage at Site 1.

\subsection{Propagation Method}

The significant influence of propagation method reported for first year survival and growth [18] and again for the same traits after five years [17] persisted through the 21-year assessment. The low survival rate of trees grown from seed was a negative impact that was consistent among species $(50 \%$ for $P$. elongata and $58 \%$ for $P$. fortunei and $P . \times$ 'Henan 1') and impossible to overcome with time, even had the surviving trees grown exceptionally well. The 21 -year $56 \%$ survival rate across species for trees grown from seed at Site 2 was similar to the $60 \%$ seven-year survival rate for $P$. tomentosa reported for seedlings grown under the best combination of treatments (pre-plant soil subsoiling and use of weed suppression mats) in a piedmont location similar to the one in this work [14]. In addition to low survival, trees grown from seed also grew poorly compared to vegetatively propagated individuals, resulting in an even wider gap in productivity. Though trees propagated through tissue culture were significantly taller than those propagated as stem cuttings, the $1.9 \mathrm{~m}$ difference may not be of practical significance, especially given that those two propagation methods resulted in trees that were indistinguishable in survival, stump diameter, DBH, and height to live crown at 21 years old. 


\subsection{Animal Waste}

The greater DBH observed at year five in trees grown with application of poultry litter compared to control trees at Site 1 [17] was again observed after 21 years. This was a surprise as the animal waste applications were made for only the first six years of the trial and because the $14 \%$ greater DBH with poultry litter application compared to the control at year 5 increased to a $26 \%$ difference after 21 years (the same difference as observed in stump diameter). As in earlier assessments, application of dairy cow waste did not influence diameter growth but did promote greater total tree height compared to control trees.

\subsection{Productivity}

Individual growth rates for trees in these trials could be very high (up to $55 \mathrm{~kg} /$ year for $P$. elongata, clone \#7) and resulted in wood production in the range of the faster Paulownia growth rates reported by Barton et al. [3]. The finding at Site 2 in the current study that Paulownia clones differed significantly in dry mass confirmed a similar finding by Berdón Berdón et al. [13]. The high-volume production of Paulownia species is accompanied by wood lightness that is second only to balsa among timber species, but the wood is much stronger than balsa $[3,16]$. Other desirable wood attributes including ability to maintain original dimensions when exposed to moisture and lower susceptibility to burning by virtue of high temperature required to cause burning make Paulownia a quality timber for engineering purposes [13]. Results from this work have application by showing Paulownia timber producers the preferred propagation method and the importance of selecting superior genotypes for enhanced timber production. However, estimates from trial-scale stands should be interpreted carefully when estimating Paulownia timber production on an operational scale.

\section{REFERENCES}

[1] Z. H. Zhu, C. J. Chao, X. Y. Lu, Y. G. Xiong. Paulownia in China: cultivation and utilization. Asian Network for Biological Sciences and International Development Research Centre, Ottawa, Canada, 1986.

[2] Y. Chong. Paulownia: The rediscovery of China's "magic tree". Agroforestry Today, Vol.1, 19-20, 1989.

[3] I. L. Barton, I. D. Nicholas, C. E. Ecroyd. Paulownia: Forest Research Bulletin No. 231. New Zealand Forest Research Institute Limited, Rotorua, New Zealand, 2007.

[4] F. A. García-Morote, F. R. López-Serrano, E. Martínez-García, M. Andrés-Abellán, T. Dadi, D. Candel, E. Rubio, M. E. Lucas-Borja. Stem biomass production of Paulownia elongata $\times P$. fortunei under Low Irrigation in a Semi-Arid Environment. Forests, Vol. 5, 2505-2520, 2014.
[5] N. Joshee. Paulownia: A multipurpose tree for rapid lignocellulosic biomass production. In: C. Kole, C. P. Joshi, D. Shonnard (eds), Handbook of bioenergy crop plants. Taylor \& Francis, Boca Raton, United States, 671-686, 2012.

[6] K. Miladinova, Y. Markovska, N. Tzetkova, K. Ivanova, M. Geneva, T. Georgieva. Photosynthesis and growth response of two Paulownia hybrid lines to heavy metals $\mathrm{Cd}, \mathrm{Pb}$ and Zn. Silva Balcanica, Vol.15, No.1, 83-99, 2014.

[7] R. Yin, Q. He. The spatial and temporal effects of paulownia intercropping: The case of northern China. Agroforestry Systems, Vol.37, 91-109, 1997.

[8] Q. Wang, J. F. Shogren. Characteristics of the crop-paulownia system in China. Agriculture, Ecosystems \& Environment, Vol.39, 145-152, 1992.

[9] J.-M. Luginbuhl, J. P. Mueller, B. A. Bergmann. Mineral concentration of herbage from three Paulownia species used for goat browse. In: J. A. Gomide, W. R. S. Mattos, S. C. da Silva (eds), Grassland Ecosystems: An Outlook into the 21st Century. XIX International Grassland Congress, São Pedro, São Paulo, Brazil, 654-655, 2001.

[10] Y. G. Xiong. Final technical report of Paulownia project (Phase II). International Development Research Centre, Ottawa Canada \& Chinese Academy of Forestry, Beijing, China, 1990.

[11] B. A. Bergmann, A. R. Rubin, R. Campbell. Potential of Paulownia elongata trees for swine waste remediation. Transactions of the ASAE, Vol.40, No.6, 1733-1738, 1997.

[12] S. B. Carpenter. This "princess" heals the land. American Forests, Vol.83, No.7, 22-23, 1977.

[13] J. B. Berdón, A. J. Montero Calvo, L. Royano Barroso, A. I. Parralejo Alcobendas, J. González Cortés. Study of Paulownia's Biomass Production in Mérida (Badajoz), Southwestern Spain. Environment and Ecological Research, Vol.5, No.7, 521-527, 2017.

[14] J. E. Johnson, D. O. Mitchem, R. E. Kreh. Establishing royal paulownia on the Virginia piedmont. New Forests, Vol.25, 11-23, 2013.

[15] T. E. Hemmerly. New commercial tree for Tennessee: Princess tree, Paulownia tomentosa Steud. (Scrophulariaceae). Journal of the Tennessee Academy of Science, Vol.64, No.1, 5-8, 1989.

[16] R. C. Tang, S. B. Carpenter, R. F. Wittwer, D. H. Graves. Paulownia - a crop tree for wood products and reclamation of surface-mined land. Southern Journal of Applied Forestry, Vol.4, 19-24, 1980.

[17] B. A. Bergmann. Five years of Paulownia field trials in North Carolina. New Forests, Vol.25, No.3, 185-199, 2003.

[18] B. A. Bergmann. Propagation method influences first year survival and growth of Paulownia. New Forests, Vol.16, 251-264, 1998.

[19] B. A. Bergmann, R. Whetten. In vitro rooting and early greenhouse growth of micropropagated Paulownia elongata shoots. New Forests, Vol.15, 127-138, 1998.

[20] World Agroforestry Centre. Tree functional attributes and ecological database: wood density, 2012. Online available 
from http://www.worldagroforestry.org/output?field_type_ tid $=63$

[21] H. Dong, J. P. van Buijtenen. A Paulownia seed source trial in east Texas and its implications to species introduction. Southern Journal of Applied Forestry, Vol.18, No.2, 65-67, 1994. 